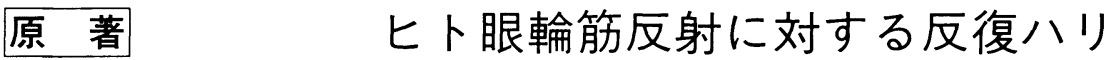 通電刺激の効果
}

\author{
錦 織 綾彦* 安雲和四郎川本 正 純 \\ 山口雄三辻 本太郎
}

要旨 単発ハリ通電刺激は眼輪筋反射の潜時の遅い成分を抑制する。 この効果の性質を詳しく調べるためハリ通電刺激に反復刺激を用いて 反射に対する影響を検討した。反射は眼窩上神経を電気刺激して誘発 し, 眼輪筋の反射性筋電図として記録した。この筋電図は刺激側のみに 出現する潜時約 $10 \mathrm{~ms}$ の成分 $(\mathrm{R} 1)$ と, 両側性に出現する潜時約 $30 \mathrm{~ms} の$ 成分 $(\mathrm{R} 2)$ からなる。ハリ通電刺激は合谷穴部の皮虐に与之た。

(1)反復ハリ通電刺激は R2を抑制した。(2)ハリ通電刺激を 10 発刺激とし て刺激頻度を $20 \mathrm{c} / \mathrm{s} \sim 2 \mathrm{c} / \mathrm{s}$ とすると, R2抑制の程度は単発時に比べて 減少した。(3)刺激頻度を $2 \mathrm{c} / \mathrm{s}$ に固定してパルス数を 2 〜 200の間で変 化させると，10以上の刺激では,(2)と同様に R2 抑制の程度は減少した。

\section{I はじめに}

針の効果には，日常臨床で繁用されている短時 間刺激によって得られるものがある。著者らは, こうした効果のうち，針刺入部位の脊髄分節を越 えて出現する効果のメカニズムを解明するために 皮膚抑制 ${ }^{122}$ が手がかりになると考えて，侵害受容 性のヒト眼輪筋反射 ${ }^{3,4)}$ とラット開口反射 ${ }^{5,6)}$ を指標 として研究を行っている。

単発ハリ通電刺激が，七ト眼輪筋反射を抑制す ることはすでに報告した ${ }^{3,4)}$ 。今回は,この抑制効果 の性質を更に詳しく検索する目的で，八リ通電刺

*Ayahiko NisHigorI 大阪大学医療技術知期大学部臨床 生理学

共同研究者：Washiro YashUmo, Mashazumi KawAMOTO, Yuzo YamaGUCHI 大阪大学医療技術知期大学部臨 床生理学, Taro Tujimoto 大阪大学医学部精神科

Key Words : 眼輪筋反射, electro-acupuncture, 皮䖉抑制, 皮膚刺激, 侵害受容性反射
激を反復刺激として，反射に対する影響を検索し た。

\section{II 方法}

（1）被 検 者

実験は，健康成人（18歳～36歳）延べ23名を対 象として行った。

(2) 眼輪筋反射

眼輪筋反射は，三叉神経第 1 枝の眼窩上神経を 経皮的に電気刺激（単発）して誘発した。反射誘 発刺激は，一側の前額部に約 $2 \mathrm{~cm}$ の間隔で装着 した 2 個の表面皿電極を通じて，持続 $0.1 \mathrm{~ms}$ の単 発矩形波(日本光電製, 電気刺激装置 SEN7103) と して与えた。刺激強度は, 反射が出現し始める強 度の 1.5 倍〜2.0倍(平均 1.7 倍) とした。反射の誘発 間隔は，慣れ現象の影響を少なくするため, $10 \mathrm{sec}$ ～20sec の間で無作為に変化させた。反射は眼輪筋 の反射性筋電困として,下眼臉部に約 $3 \mathrm{~cm}$ 離して 置いた 1 対の表面皿電極から導出して，陰極線才 シロスコープ(日本光電製VC9）で観察記録した。 

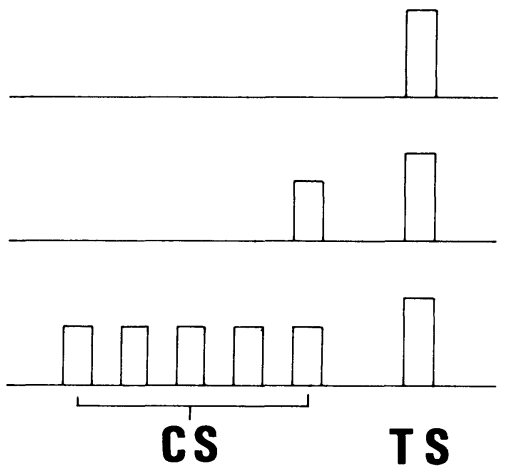

Fig. 1 刺激設定の模式図一側の眼窩上神経 に与之た単発電気刺激を試験刺激 (TS) と し，これに単発及び反復ハリ通電刺激を条 件刺激 $(\mathrm{CS})$ として先行させた。CS 終了と

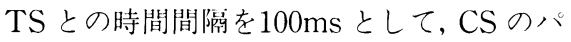
ルス数，刺激频度を変化させた。また，パ ルス数と刺激频度を固定して, CS 終了と

TSとの刺激間䧣を変化させた。

眼輪筋反射の反射性筋電図は，刺激側だけに出 現する潜時約 $10 \mathrm{~ms} の$ 成分 $(\mathrm{R} 1)$ ， 画側性の潜時 約 $30 \mathrm{~ms}$ の成分 $(\mathrm{R} 2)$ とからなる。 $\mathrm{R} 2$ は多相性であ るので定量化のため積分した。

（3）八リ通電刺激

ハリ通電刺激は，単発ハリ通電刺激の実験で効 果が著明に出現した，第 1 ，第 2 中手骨間の皮䖉 (合谷)に浅く刺入した針を関電極とし，持続 $1 \mathrm{~ms}$ の㓌性矩形波として与えた。針は皮膚を限局して刺 激する目的で，ステンレス針(直径 $0.1 \mathrm{~ms}$ )を針尖 部を除いて絶縁して用いた。不関電極は幅 $1 \mathrm{~cm} の$ 湿性電極として，関電極と同側の前腕上部に巻き つけた。ハリ通電刺激の強度は，八リ通電刺激と 反射誘発刺激の刺激間隔を（単発ハリ通電刺激に よって反射が最も強く抑制される） $100 \mathrm{~ms} に$ 設定 して，R2がコントロールの50\%以下に抑制される 強度とした。この強度は刺激を感じ始める強度の 1.6倍〜2.5倍（平均 2.0 倍）であった。

(4) 刺激設 定

ハリ通電刺激を条件試験 conditioned stimulus (CS) としし, 反射誘発刺激を試験刺激 test stimulus (TS)として以下の実験を設定した。

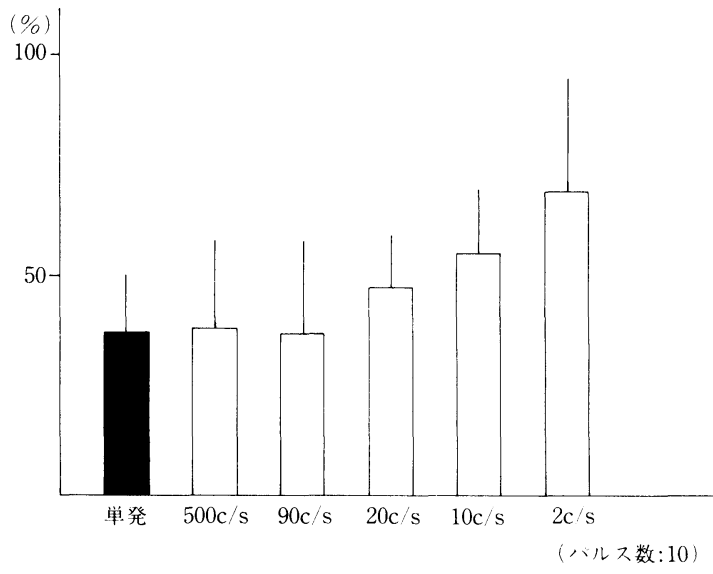

Fig.2R2に対する反復ハリ通電刺激 (CS)の 効果, I , 刺激頻度の影響 CS を10発の train pulse としてTSに100ms 先行させ て合谷に与えた。刺激频度は $500 \mathrm{c} / \mathrm{s} \sim 2 \mathrm{c} / \mathrm{s}$ の間で変化させた。縦軸はコントロールの $\mathrm{R} 2$ 積分值を $100 \%$ として表示し，横軸は刺 激频度を表示した。黑色の棒グラフは，R2 に対する単発ハリ通電刺激の效果を示した。

1) $\mathrm{CS}$ のパルス数を 10 とて, CS 終了と $\mathrm{TS} の$ 刺激間隔を $100 \mathrm{~ms}$ に固定し, CSの頻度を $2 \mathrm{c} / \mathrm{s} \sim 500$ $\mathrm{c} / \mathrm{s} の$ 間で変化させた。

2） CSとTSの刺激間隔は 1)と同様の設定とし て，CSのパルス数を 2 200の間で変化させた。

3） CSのパルス数と刺激頻度をそれぞれ 10,2 $\mathrm{c} / \mathrm{s}$ して, CS 終了後 $100 \mathrm{~ms} \sim 300 \mathrm{~ms}$ の間でTSを与 えた。

眼輪筋反射の 2 は, 被検者が反射誘発刺激の到 来をあらかじめ知り，その刺激に注意を向けた際 に抑制される゙。こうした精神生理学的な因子の影 響を除外するため，刺激は 1$) ， 2 ， 3) の$ 設定内で 無作為に与えた。

Fig. 1 は刺激設定の模式図である。

\section{III 結 果}

1） CSのパルス数を 10 とし，刺激頻度を $2 \mathrm{c} / \mathrm{s}$ $500 \mathrm{c} / \mathrm{s}$ の間で変化させると, $20 \mathrm{c} / \mathrm{s}$ の場合 $\mathrm{R} 2$ の反 応量はコントロールの $45.5 \% \pm 11.5 \%$ (平均值士標 準偏差）に抑制された。これに対し単発刺激では, $38.0 \% \pm 12.8 \%$ に抑制され，両者のR2 抑制量に有 


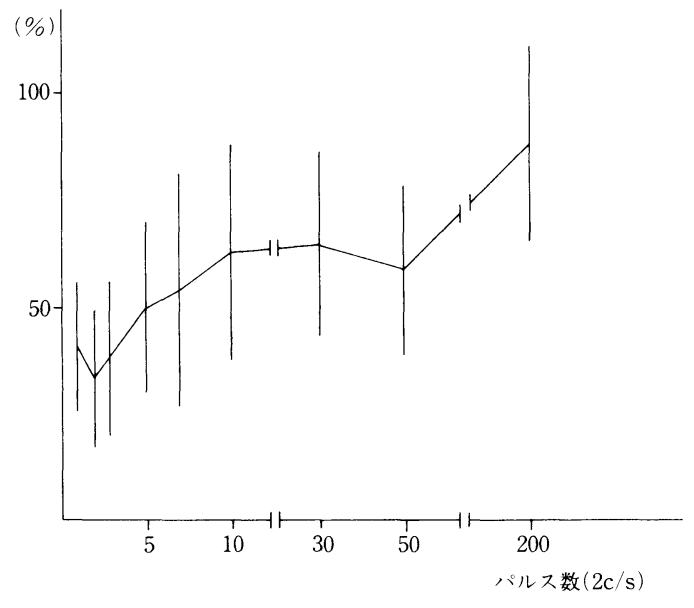

Fig. 3 R2 に対する反復ハリ通電刺激 (CS) の 効果, II, 刺激数の影響 $\mathrm{CS}$ を $2 \mathrm{c} / \mathrm{s}$ と し, パルス数を 1 ～200の間で変化させて, TSに $100 \mathrm{~ms}$ 先行して合谷に与えた。縦軸 はコントロールの積分值を $100 \%$ とし, 横軸 は CSのパルス数を表示した。

意差 $(\mathrm{n}=76, \mathrm{tcal}=2.49)$ を認めた。 CS の刺激頻 度を $20 \mathrm{c} / \mathrm{s}$ より減少させると両者の差は更に著明と なった。刺激頻度が $90 \mathrm{c} / \mathrm{s}$ 以上の場合両者に差はな かった(Fig. 2 )。CSの刺激頻度 ( c/s) とR2反応量 （対コントロール比）の間に負の相関 $(n=192, r=$ -0.69）があった。

2) $\mathrm{CS}$ の刺激頻度を $2 \mathrm{c} / \mathrm{s}$ とて，パルス数を 2 200の間で変化させた場合, パルス数を 5 とす ると，R2の抑制量は減少する傾向がみられた。パ ルス数10の場合， R2 はコントロールの $63.2 \% \pm$ $25.0 \%$ までしか抑制されず，単発の場合 $(41.3 \%$ $\pm 15.2)$ に比較して抑制されにくくなった $(\mathrm{n}=122$, $\mathrm{tcal}=6.20)$ 。パルス数を増加するとR2は更に抑制 されにくくなり，200の場合R2 はコントロールの $89.3 \% \pm 20.4 \%$ となり，ほとんど抑制されなかっ た(Fig. 3 )。CSのパルス数とR2の反応量の間に正 の相関があった $(\mathrm{n}=299, \mathrm{r}=0.57)$ 。

3) $\mathrm{CS} 2 \mathrm{c} / \mathrm{s}$, パルス数 10 とし, CS終了と TS の時間間隔を $100 〜 300 \mathrm{~ms}$ の間で変化させた場合, $100 \mathrm{~ms}$ でR2はコントロールの $67.0 \% \pm 32.9 \%$ に抑 制され，200ms，300msの場合もほぼ同程度抑制

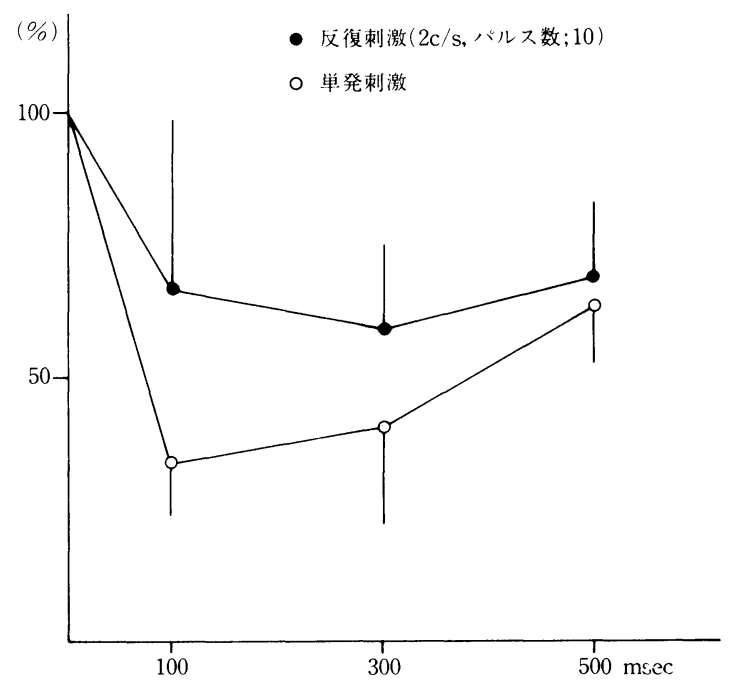

Fig. 4 反復ハリ通電刺激と単発ハリ通電刺激 の R2 抑制効果の比較 反復ハリ通電刺激 (・— - $2 \mathrm{c} / \mathrm{s}, 10$ 発の train pulse とし て, TSに100 300ms 先行させて合谷に与 之, 単発ハリ通電刺激 ( O 一 ) の場合と比 較した。縦軸はコントロールの R2 積分值 を $100 \%$ として, 横軸は CS と TSの刺激間 隔 (ms) を表示した。

された。一方，単発刺激ではR 2 は $100 \mathrm{~ms} て ゙$ 最も抑 制 $(33.1 \% \pm 11.7 \%)$ され，反復刺激の場合に対 して有意差 $(\mathrm{n}=42, \mathrm{tcal}=2.94)$ を認めた $(\mathbf{F i g . ~} 4)$ 。 以上 1)，2），3）いずれの場合にも R 1 に著明な 変化はなかった。

\section{〔刺激に対する被検者の内省報告〕}

○反復ハリ通電刺激による感覚は単発刺激の場合 に比較して強く感じ, 単発刺激時に痛みを感じ ない場合でも，痛みを感じることがある。

○刺激頻度が $20 \mathrm{c} / \mathrm{s}, 10 \mathrm{c} / \mathrm{s}, 2 \mathrm{c} / \mathrm{s}$ の際には，パル ス数が増すに従い累加的に痛みを強く感じた。 ○パルス数を 10 以上に増加させた際にも刺激を弱 く感じることはなかった。

○反射誘発刺激による感覚は, 反復刺激を先行さ せると弱く感じ, 単発刺激の場合に比べて大き な差異はなかった。

\section{$\mathrm{V}$ 考察}

針の遠隔効果には，針麻酔刺激等の長時間刺激 
によるものと，日常使用される短時間刺激による ものとがある。この効果のうち春髄の分節を越え て出現する効果を解明するためのモデル実験の 1 つとして，侵害受容性のヒト眼輪筋反射を指標と した実験がなされている。

Boureau $ら^{8)}(1979)$ は，眼輪筋反射が針麻酔刺 激によって抑制されることを明らかにした。更に この抑制がナロキソンによって拮抗されることか ら, 内在性モルフィン様物質の関与を示唆した。 一方, 著者ら ${ }^{3,4}(1980)$ は, 短時間刺激のモデルと して単発ハリ通電刺激を用いて，これが眼輪筋反 射を抑制することを報告し，この効果は広範な皮 膚に起源を持つ皮膚抑制であると考えられること を示した。

この様に針の遠隔効果の出現には，少なくとも 質的に異なる 2 つメカニズムが関与すると考え られる。

（I） 反復ハリ通電刺激の効果とその出現メカ ニズム。

単発ハリ通電刺激の効果の持続時間は約 1 秒と 短かい。そこで今回の実験では，効果の増強を期 待して，ハリ通電刺激を反復刺激としてその効果 を検討した。しかし，結果はハリ通電刺激のパル 又数を増加した場合, 効果は増強されずむしろ減 弱された。この様な現象は，ハリ通電刺激による 入力の相互作用によって，それぞれの効果が打ち 消された結果出現すると考之られる。Jabbur ら ${ }^{2}$ (1970)は，猫の後索核で広範な皮䖉からの入力が， 抑制性の相互作用を受けることを示した。こうし たメカニズムが，本実験での相互作用の基礎にあ ることは疑いないと思われる。

（II）実験結果と臨床の関連

ハリ通電刺激を $2 \mathrm{c} / \mathrm{s}$ とた際のパルス数と $\mathrm{R} 2$ 反応量との間，またパルス数を 10 とた際の刺激 頻度とR2反応量の間に，それぞれ正抢よび負の相 関があった。すなわち, 反復ハリ通電刺激の効果 は，そのパルス数に比例して減少し，刺激頻度に 逆比例して減少する。こうした現象はヒト眼輪筋 反射に特異的ではなく，ラット開口反射（歯髄刺 激, 眼窩下神経刺激による)を指標とした際にも, ハリ通電刺激を反復刺激とした際に観察される。

以上のことから，今回の結果は日常臨床で刺針
によって得られた効果が，更に刺激を付加された 時に減弱したり消失することと関係があることを 示唆し，更にその出現には，付加された針の刺激 パターンが関係することを示唆している。

一方，内省報告によると，被検者は単発ハリ通 電刺激より反復刺激の方を強く感じたという。し かし，抑制効果は単発刺激の方が強く出現した。 これは痛み等の強い感覚を伴う施針が，必ずしも 有効とは限らないことに対応すると思われる。

\section{VI まと め}

1. 反復ハリ通電刺激は, 眼輪筋反射の $\mathrm{R} 2$ を抑制し た。しかし，抑制量は単発刺激時に比較して減 少した。

2.R2抑制量は，ハリ通電刺激のパルス数を10とし た場合, $2 \mathrm{c} / \mathrm{s} \sim 20 \mathrm{c} / \mathrm{s}$ の刺激頻度で減少した。 刺激頻度を $2 \mathrm{c} / \mathrm{s}$ とた場合では,パルス数を 10 〜200とした際に減少した。

3.こうした現象は，臨床で刺針によっていったん 得られた効果が, 追加された刺激によって減弱 することと関係があると考える。

(本論文の要旨は昭和56年 5 月 24 日, 第31回本学会名古屋 学術大会において発表した)

\section{引用文献}

1) By E. D. Adrian : Afferent discharges to the cerebral cortex from peripheral sense organs, J. physiol. 100, 159 - 91. (1941)

2) S. J. Jabbur and N. R. Banna : Widespread cutaneous inhibition in dorsal column nuclei, J. Neurophysiol. $33 ; 616 \sim 624$. (1970)

3）安雲和四郎, 山口雄三ほか: ハリ刺激時の眼輪 筋反射, 日本銊炎治潦学会誌 29 ( 3 ) 36 4 4 . (1980)

4）錦織綾彦，山口雄三ほか：ハリ通電刺激による 皮虐抑制，自律神経雓誌 $27(2 \cdot 3) 274 \sim 275$.

(1980)

5）安雲和四郎，山口雄三ほか：ハリ通電刺激によ るラット開口反射の抑制，日本鍼炎治療学会誌 30 ( 3 ) ;204 208. (1981)

6）安雲和四郎, 山口雄三ほか：ハリ通電刺激の侵 害受容性反射に及ぼす影響ーラット開口反射の 場合一, 全日本銊炎学会雑誌 31（3)；247～251. (1981) 
7）錦織綾彦, 山口雄三ほか：選択的注意集中と眼 輪筋反射, 脳波と筋電困 10(1);48. (1982)

8) F. Boureau, Y. Yamaguchi. et al.: Abolition par la naloxone de l'effet inhibiteur d'une stimulation électrique périphérique sur la com- posante tradive du réflexe de clignement, Electroenceph. clin. Neurophsiol. 47(3);322 328. (1979)

(干577 東大阪市中鸿池町1-6-2-406 1983年 6 月 24 日受付)

\title{
Effects of repetitive electro-acupuncture stimulation on the human blink reflex
}

\author{
Ayahiko Nishigori, Yuzo Yamaguchi, et al. \\ Laboratory of clinical physiology, College of Biomedical Technology, Osaka University \\ Taro Tujimoto. \\ Department of Neuropsychiatry, Osaka University Medical School.
}

\section{Summary}

Effects of repetitive electro-acupuncture stimulation on the blink reflex were studied in 23 healthy adults. The blink reflex was elicited by an electrical stimulus of the supraorbital nerve. The reflex EMG's were recorded from the orbicularis oculi muscle. The EMG's were composed of the early component (R1), ipsilaterel to the supraorbital stimulation, with about $10 \mathrm{~m} \mathrm{sec}$ latency and the bilateral late ones (R2) with about $30 \mathrm{~m}$ sec latency. Electro-acupuncture stimulations consisting of single pulse and a train pulse were given to the skin on "Hogu" point, respectively.

Single pulse electro-acupuncture stimulation inhibited the R2 components for $30 \mathrm{~m} \mathrm{sec}$ to $1 \mathrm{sec}$ after the stimulation and its inhibitory effect reached maximum about $100 \mathrm{~m} \mathrm{sec}$ after it. The R2 components were also suppressed when the skin was stimulated by a train of ten pulses with frequency of $2 \mathrm{c} / \mathrm{s}$ to $20 \mathrm{c} / \mathrm{s}$, but the inhibitory effect decreased significantly compared with that of single pulse stimulation. The inhibitory effect was also diminished by 10 to 200 pulses electroacupuncture stimulation with a frequency of $2 \mathrm{c} / \mathrm{s}$. 